\title{
A regional arrangement proposal for the UNASUR
}

\section{FERNANDO FERRARI-FILHO*}

The article analyses the current process of economic integration in South America. Thus, concentrating our attention on the UNASUR regional integration process, two questions arise: First, is UNASUR the most viable institution to achieve a consistent economic integration process in South America? Second, what model of economic integration should be adopted in the case of UNASUR, which would ensure macroeconomic stability and avoid financial and exchange rate crises in the South America? To answer these questions, the article proposes, based on the Keynes (1944/1980)'s revolutionary analysis presented in his International Clearing Union, during the Bretton Woods Conference in 1944, a regional arrangement to UNASUR.

Keywords: economic integration; South America; Keynesian theory.

JEL Classification: F5; F55.

\section{INTRODUCTION}

The international financial crisis and the 'great recession' have substantially altered the dynamic process of the international economy. The effects of such a crisis and recession are not economically and socially neutral; as a result, the benefits of financial globalization have come to be called seriously into question. While this crisis is associated with an absence of regulation, particularly by the State, it has been action by Big Bank and Big Government that has prevented it from developing into a depression ${ }^{1}$.

\footnotetext{
* Full Professor of Economics at the Federal University of Rio Grande do Sul and Researcher at CNPq. E-mail: ferrari@ufrgs.br. This article is a revised and expanded version of Arestis and Ferrari-Filho (2012). I would like to thank an anonymous referee for comments and suggestions. All remaining mistakes are the author's responsibility. Submitted: 16/January/2013; Approved: 28/August/2013.

${ }^{1}$ We employ the wording of Minsky (1986, chapter 13) in the text, according to which the failures of
} 
Moreover, the 'great recession' has generated a debate about the necessity of restructuring the international monetary system (IMS), a necessary condition for the world economy to return to stability and healthy economic growth. In short, and ever since 2007, the G-20 meetings and other international organizations have proposed, in their attempt to avert any worsening of the 'great recession', to monitor and regulate the financial system and to negotiate a 'new architecture' for the IMS so that financial markets could return to performing their primary function which is to finance productive investment and consequently expand effective world demand. Unfortunately, the conservatism and conflicts of interest among the member countries of the G-20 have prevented any progress towards the possible restructuring of the IMS, at least for the present. In addition, the G-20 retreated from its initial position, preaching fiscal prudence.

In view of these developments, especially the pessimism about the progress of deeper reforms in the IMS, regional integration has become a second best strategy for the developing countries, specifically for South America countries.

Since the 2000s, as a result of the stagnation of the Free Trade Area of the Americas (FTAA) negotiations, the South American integration process has experienced important changes, such as, the creation of the South America Community of Nations (CASA), in 2004, the creation of the Union of South America Nations (UNASUR), in 2007, and the implementation of some 'institutionalities' in the Common Market of the South (MERCOSUR). Thus, the debate on the need to consolidate a process of economic integration more consistently and robustly in South America - based on monetary and financial cooperation to ensure macroeconomic stability and avoid financial and exchange rate crises in the South American countries and the creation of a development bank to finance the regional infrastructure (roads, transportation, telecommunications, power generation and transmission etc.) - has come to be on the agenda. This point is corroborated by UNCTAD (2007), which argues that there is no better alternative available to the major emerging economies, including South American economies, than regional integration.

In this context and concentrating more closely on the UNASUR regional integration, two questions arise: First, is UNASUR the most viable institution to achieve a consistent economic integration process in South America? Second, what model of economic integration should be adopted in the case of UNASUR, which would ensure macroeconomic stability and avoid financial and exchange rate crises in the South America?

This contribution attempts to answer these questions by concentrating on the following objectives: First, it aims to show that UNASUR may be an interesting project of economic integration to prevent disruptive economic situations in the

capitalism can be solved only by creating the Big Bank, a lender-of-last-resort function, to avoid financial system collapse, and Big Government, to assure fiscal stimulus and State intervention to stabilize output and employment. 
South American countries. Second, it proposes, inspired in Keynes (1944/1980)'s revolutionary analysis presented in his International Clearing Union, during the Bretton Woods Conference in 1944, a regional arrangement to UNASUR to assure long-term economic growth and social development in the Region. The idea is that this regional integration proposal will become more consistent the higher the convergence of the macroeconomic policies is, simply because it can induce trade and financial cooperation ${ }^{2}$.

To address this objective, besides this Introduction, the article has more three sections: Second section presents a brief historical analysis of the economic integration process in South America and analyses some selected macroeconomic variables of the member countries of UNASUR to observe if these economic data are (or not) converging. Third section, based on Keynes (1944/1980), presents a regional arrangement proposal for UNASUR. The last section summarizes and concludes.

\section{UNASUR: A BRIEF HISTORICAL ANALYSIS AND THE CURRENT STAGE OF INTEGRATION}

\section{A brief history of the integration economic of South America}

According to Baumann (2001), the economic integration process in South America can be divided into three periods: from the 1960s to the 1970s, the regional integration was characterized by a strong State presence and gradual reduction of trade tariffs; in the 1980s the bilateral agreements were predominant; and, since the 1990s, the economic integration has been determined by monetary and financial cooperation and the creation of regional arrangements.

Historically, the idea of economic integration in South American began in 1960 when some trade agreements were signed within the Latin America Free Trade Association (ALALC). ALALC was an unsuccessful attempt to create a free trade area in the Latin America. The member countries were Argentina, Brazil, Chile, Mexico, Paraguay, Peru and Uruguay. In 1970, Bolivia, Colombia, Ecuador and Venezuela became member countries of ALALC. In 1980, ALALC was replaced by Latin America Association for Integrated Development (ALADI). At that time, Cuba also became a member country of ALADI.

Concomitantly to the proposal of having a wider regional integration in Latin America, such as ALADI, in the late 1960s and early 1990s two sub-regional blocs were created: the Andean Community of Nations (CAN) and MERCOSUR.

\footnotetext{
${ }^{2}$ Despite the fact that this contribution emphasizes the main aspects of the relevant macroeconomic policies, it is important to emphasize that industrial policies, infrastructure investment and educational policies are key issues to reduce the asymmetries among the UNASUR countries. It is also important to emphasize the need for relevant political institutions as well a social and cultural integration, which are all relevant in the integration process. They are not discussed in the contribution in view of space limitation.
} 
CAN was created, in 1969, to achieve a sustainable and balanced economic and social development in the Andean region (CAN, 2013). The original member countries of CAN were Bolivia, Chile, Colombia, Ecuador, Peru and Venezuela. In 1977, due to political reasons, Chile decided to leave CAN and in 2006 Venezuela also left CAN to join MERCOSUR as an associate country ${ }^{3}$.

In 1991 the Asunción Treaty, signed by Argentina, Brazil, Paraguay and Uruguay, created MERCOSUR. MERCOSUR was created to be an economic and political agreement among Argentina, Brazil, Paraguay and Uruguay. Its purpose is to promote free trade area in the Region. Actually, it is a Customs Union, but, in the past, some MERCOSUR Economic Authorities proposed a regional and common currency to MERCOSUR ${ }^{4}$. In 2012, Venezuela became a member country of the MERCOSUR.

In the 2000s, CAN and MERCOSUR, the main economic integration blocs of the South America, went through periods during which questions were raised in terms of disappointing trade performance, as well as in terms of political and diplomatic experience. In this context, to avoid the weakening of these economic blocs, in 2004 CASA was created to stimulate the economic agreements between CAN and MERCOSUR, and, in 2007, CASA was replaced by UNASUR — from a treaty signed between the CAN and MERCOSUR members - to be an alternative and a more consistent project of economic integration in South America ${ }^{5}$. The main objectives of UNASUR are: political coordination, free trade agreement, infrastructure integration - especially, in terms of energy and communications -, financial integration, cooperation in technology, science, education and culture, integration between business and civil society and integration and regional development (UNASUR, 2013).

All countries of South America are permanent members of UNASUR, which are Argentina, Bolivia, Brazil, Colombia, Chile, Ecuador, French Guiana, Guyana, Paraguay, Peru, Suriname, Uruguay and Venezuela.

The population estimation of UNASUR, in 2010, was around 390 million people.

In 2011, the GDP of UNASUR countries, at current prices, was around USD 4.2 trillion $^{6}$. Table 1 shows the GDP per capita and the Human Development Index (HDI) of South American countries.

\footnotetext{
${ }^{3}$ In 2012, Venezuela became a member country of the MERCOSUR. Bolivia, Chile, Colombia, Ecuador and Peru are associated countries.

${ }^{4}$ For more details about MERCOSUR and a critical assessment of the creation of a currency union in MERCOSUR, see, respectively, Arestis, Ferrari-Filho, Paula and Sawyer (2003) and Ferrari-Filho (20012002).

${ }^{5}$ It is important to mention that the creation of the UNASUR overlaps the integration processes of CAN and MERCOSUR.

${ }^{6}$ The GDP calculation has been undertaken by the author based on statistical information from UNCTAD (2013) and ECLAC (2013).
} 
Table 1: GDP Per Capita and HDI of the South American Countries in 2011

\begin{tabular}{|c|c|c|}
\hline Country & GDP Per Capita (USD Current Prices) & HDI \\
\hline Argentina & 17,516 & 0.797 \\
\hline Bolivia & 4,789 & 0.663 \\
\hline Brazil & 11,769 & 0.718 \\
\hline Chile & 17,222 & 0.805 \\
\hline Colombia & 10,249 & 0.710 \\
\hline Ecuador & 8,492 & 0.720 \\
\hline French Guiana & 19,728 & n.a. \\
\hline Guyana & 7,465 & 0.633 \\
\hline Paraguay & 5,413 & 0.665 \\
\hline Peru & 10,062 & 0.725 \\
\hline Suriname & 9,475 & 0.680 \\
\hline Uruguay & 15,113 & 0.783 \\
\hline Venezuela & 12,568 & 0.735 \\
\hline Average & 11,528 & 0.719 \\
\hline
\end{tabular}

Note: n.a. means not available.

Source: IMF (2013a) and UNDP (2013).

Observing the steps of the South American integration process, since the 2000s the economic integration in the Region has become more dynamic. Besides the tariff and trade agreements implemented in the Region, a set of institutional bodies were created to boost the economic integration in the South America, such as:

- Structural Convergence Fund of the MERCOSUR (FOCEM): this was created in 2004 and implemented in 2005 to operate "political and economic instrument[s] to reduce existing structural asymmetries among countries and promote competitiveness and social cohesion primarily in less developed countries and regions" (IADB, 2005, p. 3). Brazil is the largest contributor to the FOCEM, contributing $70 \%$ of its total resources. Argentina contributes $27 \%$ and Uruguay and Paraguay contributions are, respectively, $2 \%$ and $1 \%$.

- Bank of the South (Banco del Sur): this was created in 2007 and its main objective is to finance and integrate the member countries of UNASUR. The task this Bank is, on the one hand, to lend money to the member countries of UNASUR for the development of social programs and construction of infrastructure projects ${ }^{7}$, and, on the other hand, it aims at encouraging regional economic development in the Region. In other words, the Bank of the South is an alternative to the IMF and World Bank.

\footnotetext{
${ }^{7}$ It is important to mention that the Bank of the South is not yet in operation because Brazil and Uruguay do not ratify their accession.
} 
- The Payment System on Local Currency (SML): in October 2008, Argentina and Brazil launched a payment system for bilateral commercial operations with their local currencies, peso and real, respectively. SML aims at eliminating the USD as an intermediary of commercial relations between the two countries.

- Single System of Regional Compensation of payments (SUCRE): in 2009, the governments of the Bolivarian Alliance for the People of Our America (ALBA), a political institution ${ }^{8}$, decided to implement the SUCRE for trade relations among their member countries. SUCRE was launched in 2010 and, since then, it has allowed the offsetting of the liabilities and assets related to the commercial transactions among the member countries. In other words, the SUCRE aims at reducing member countries dependence on the USD as a reserve currency and as the basis of intraregional trade.

It is important to mention that the creation of these 'institutionalities', together with the Latin American Reserve Fund (FLAR) and Reciprocal Payments and Credits Agreement (RPCA) ${ }^{9}$, are important to South America because they boost the monetary and financial cooperation, stimulate sustainable development by financing infrastructure projects and improve the foreign reserves of the South American countries to support their balance of payments problems.

To sum up, the economic integration process in South America became reality in the 2000s, especially after the implementation of UNASUR, due to, at least, two reasons: first, it created a set of institutional bodies that allow greater monetary, financial and fiscal cooperation among the South American countries; and second, policymakers and international institutions have argued for the restructuring of the global economic order once the 'great recession' has ended, encompassing both restructuring of the IMS and the speed up of the economic regional integration process.

\section{The current stage of economic integration of UNASUR}

As sub-section 1 shows, in South America the fiscal, monetary and financial integration is back to the negotiating agenda. It has created new mechanisms of cooperation, such as the FOCEM, the Bank of the South and the use of the Argentine peso and the Brazilian real as currencies to enable international transactions.

\footnotetext{
${ }^{8}$ The member countries of ALBA are Antigua and Barbuda, Bolivia, Cuba, Dominica, Ecuador, Nicaragua, Saint Vincent and the Grenadines and Venezuela.

${ }^{9}$ FLAR is a financial institution created in 1978 whose main objective is to support its member countries (Bolivia, Colombia, Ecuador, Peru, Uruguay, Venezuela and Costa Rica) with balance of payments problems. It is considered the Andean version of International Monetary Fund (IMF); and RPCA is an agreement created in 1982 in order to allow the creation of a Reserve Fund to support the balance of payments, guarantee loans and improve the official reserves of the central banks of the member countries of ALADI. In other words, its main objective is the establishment of a regional payment agreement.
} 
Thus, in this new context, this sub-section aims to analyze the current stage of economic integration in UNASUR, in terms of monetary and financial integration and convergence of macroeconomic variables, in attempt to speculate about what process of economic integration is more appropriate for UNASUR. For this purpose, our methodology consists of discussing the evidence on real and monetary-financial integration process among the countries of UNASUR. This will be undertaken in terms of some selected macroeconomic variables.

Before presenting and analyzing the current stage of economic integration in UNASUR, three clarifications on the methodology are in order: First, we will exclude from our analysis French Guiana, Guyana and Suriname, because the economic statistics for these countries are not fully available. Thus, UNASUR will consist of Argentina, Bolivia, Brazil, Colombia, Chile, Ecuador, Peru, Paraguay, Uruguay and Venezuela. In fact, the exclusion of these countries does not make so much difference, especially in terms of GDP: in 2011, the total GDP of French Guiana, Guyana and Suriname, at current prices, was around USD 10.7 billion; this represents, approximately, $0.25 \%$ of total GDP of the other 10 countries of UNASUR. Second, the macroeconomic variables we have chosen are average GDP growth rate, average inflation rate, unemployment rate, intraregional trade, current account/GDP, nominal fiscal result/GDP, gross public debt/GDP and foreign reserves. We also present some comments about the exchange rate and monetary regimes of each country. In other words, analyzing these variables, we are in effect studying, directly and indirectly, the behavior of the main macroeconomic policies, fiscal, monetary and exchange rate ${ }^{10}$. Third, the period analyzed is from 2000 to 2010.

We may begin with the evidence on GDP, inflation rate and unemployment rate among the countries of UNASUR. According to the author's calculations, based on statistical information from ECLAC (2013) and IMF (2013b), the figures indicate that over the period:

- The average GDP growth rate for all countries of UNASUR was around 3.8\% per year ${ }^{11}$. Five countries (Argentina, Bolivia, Brazil, Chile and Colombia) presented an average GDP growth rate per year similar to $3.8 \%$ per year for all countries, two countries (Ecuador and Peru) had an average GDP growth rate per year greater than the average GDP growth rate of all 10 countries and the average GDP growth rate per year for three countries (Paraguay, Uruguay and Venezuela) increased less than the average GDP growth rate for all countries.

\footnotetext{
${ }^{10}$ We know that the macroeconomic policies and variables, probably, were affected by exogenous factors, such as international financial crisis and 'great recession'. However, for purposes of simplification, we will not analyze theses issues.

11 The average growth rates of Argentina, Bolivia, Brazil, Chile, Colombia, Ecuador, Paraguay, Peru, Uruguay and Venezuela were, approximately, $3.9 \%, 3.8 \%, 3.7 \%, 3.8 \%, 4 \%, 4.3 \%, 3.3 \%, 5.3 \%, 2.8 \%$ and $3 \%$.
} 
- The average inflation rate for all countries of UNASUR was $8.1 \%$ per year, relatively low considering the historically of high inflation rates in South America during the 1980s and 1990s ${ }^{12}$. Six countries (Bolivia, Brazil, Chile, Colombia, Paraguay and Peru) had an average inflation rate per year lower than the average inflation of all countries, with two countries (Argentina and Uruguay) presenting an average inflation rate slightly above the average inflation rate of $8.1 \%$ per year, and two countries, Ecuador and Venezuela, had an average inflation rate per year greater than the average inflation rate of UNASUR countries.

- The unemployment rate was relatively high at the beginning of the 2000s, reaching double digits, for almost all UNASUR countries (the exceptions were Brazil and Paraguay). At the end of the 2000s the unemployment rate for almost all countries, with the exception of Colombia, dropped substantially (the average unemployment rate was around a $7.4 \%$ per year).

In terms of the exchange rate and monetary regimes of the UNASUR countries, we have the following: Argentina in 2001 had a currency board regime and since 2002 it has adopted a managed exchange rate regime ${ }^{13}$; Bolivia has a flexible exchange rate regime; Brazil operates a dirty floating regime in the context of an inflation targeting monetary regime; Chile, like Brazil, operates a dirty floating regime in the context of an inflation targeting monetary regime; Colombia adopts a dirty floating regime and its monetary regime is based on inflation targeting; Ecuador is 'dollarized' and adopts a flexible exchange regime with free convertibility; Paraguay has a dirty floating regime and, recently, adopted an inflation targeting regime; Peru also operates a dirty floating regime in the context of an inflation targeting monetary regime; Uruguay adopts an inflation targeting regime and has a flexible exchange rate regime; and Venezuela, at the beginning of the 2000s, ran a managed exchange rate regime, and, more recently, decided to control the exchange rate to avoid the 'exchange rate pass-through' mechanism, and continued as the only country to control its foreign currencies and manipulator of this devaluation experience. In summary, seven countries 'manage' their exchange rates, one country adopts USD as legal tender and two countries operate a flexible exchange rate regime.

The intraregional trade (total volume of exports and imports to the Region/

\footnotetext{
12 The average inflation rates of Argentina, Bolivia, Brazil, Chile, Colombia, Ecuador, Paraguay, Peru, Uruguay and Venezuela were, approximately, $8.2 \%, 5 \%, 5.3 \%, 3.5 \%, 5.1 \%, 12.5 \%, 7.1 \%, 2.5 \%, 8.3 \%$ and $21.3 \%$.

${ }^{13}$ The stable and competitive real exchange rate strategy was a result of the exchange rate administration by the Central Bank of Argentina and its intervention in the monetary market to control the interest rate. However, since the international financial crisis, due to the deterioration trend in the trade surplus, Argentina's government has responded by implementing administrative controls in the foreign exchange market, in order to seek to avoid a further deterioration of its exchange rate.
} 
Total UNASUR GDP) among the UNASUR countries increased $176.1 \%$ between 2000 and 2010: in 2000, the intraregional trade was around USD 73.1 billion and in 2010 it reached a total of USD 201.8 billion. However, its importance compared to GDP is still very low, as Figures 1 and 2 show, and this intraregional trade expansion, in terms of UNASUR GDP, remained relatively stable; in 2000, the ratio of total exports plus imports to UNASUR GDP was $5.5 \%$, while in 2010 this relationship increased to $5.8 \%$. As the figures show, the intraregional trade of UNASUR has increased and it has been important for Bolivia and Paraguay, while the intraregional trade of UNASUR has been irrelevant for Brazil and Venezuela. Moreover, the share of UNASUR exports in world trade is still relatively low; it increased from $2.5 \%$, in 2000 , to $3.4 \%$, in $2010^{14}$.

Figure 1: Intraregional Trade (Exports + Imports/GDP), 2000-2010

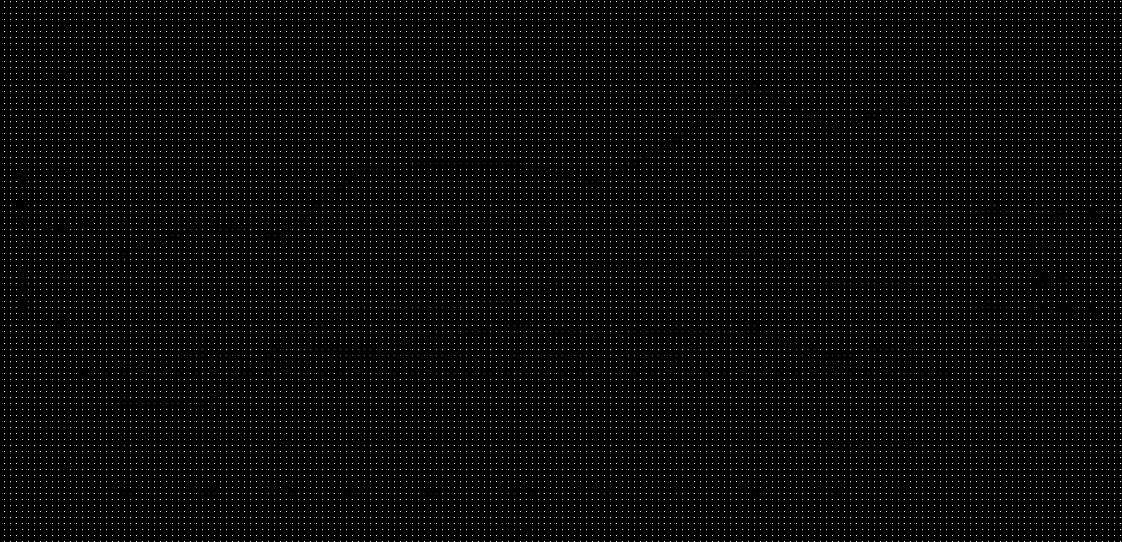

Source: ECLAC (2013).

${ }^{14}$ Author's calculations based on statistical information from UNCTAD (2013). 
Figure 2: Intraregional Trade (Exports + Imports/GDP), 2000-2010

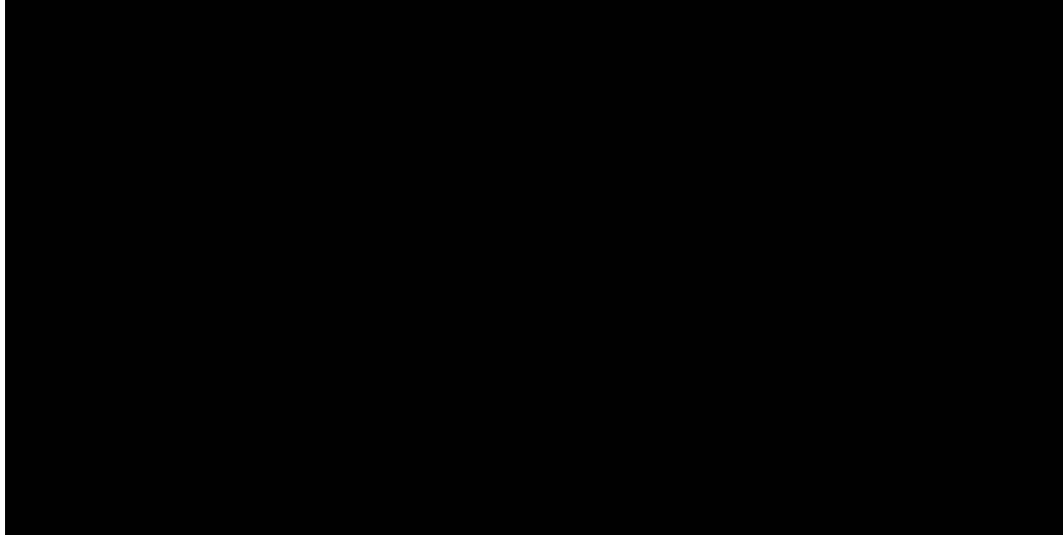

Source: ECLAC (2013).

Looking at the data relating to the current account deficits, Figures 3 and 4, it is possible to observe the following:

- In the period 2000-2002, almost all of UNASUR countries had high current account deficits to $\mathrm{GDP}^{15}$. In our view, at least three reasons explain this performance: (i) the Argentinean and Brazilian exchange rate crises, respectively in 2001-02 and 2002, ended up affecting the economic dynamics of other countries in the Region; (ii) the slowdown of the world economy, particularly the United States, reduced the demand for South American products; and (iii) the commodity prices (agricultural and mineral - especially copper and iron) of the UNASUR exports fell, basically from 2001 to 2003 (UNCTAD, 2008).

- From 2003 to 2007, the current account of almost all UNASUR countries turned into surplus. During this period, the world economy showed high growth and the commodity prices increased considerably.

- From 2008 to 2010, the current account deteriorated due to the 'great recession'. Despite this deterioration, the current account deficits were still better than those observed in the beginning of the 2000s.

\footnotetext{
${ }^{15}$ It is necessary to clarify two things: on the one hand, we are not concerned in showing if the ratio current account deficit/GDP in the 2000s, for all UNASUR countries, was better or worse compared to previous decades, especially in the beginning of the 1980s, during the Latin American debt crisis, and in the mid-1990s. On the other hand, we are neglecting the possible relationship between the deterioration of the current account deficit and domestic demand growth of the UNASUR countries.
} 
Figure 3: Current Account/GDP, 2000-2005

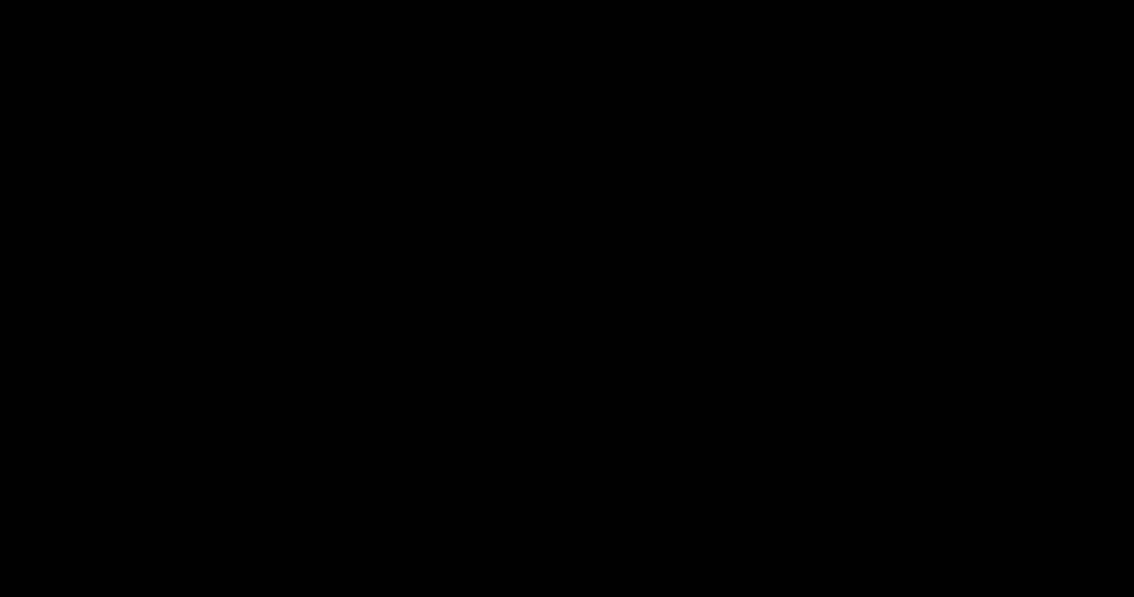

Source: IMF (2013b)

Figure 4: Current Account/GDP, 2006-2010

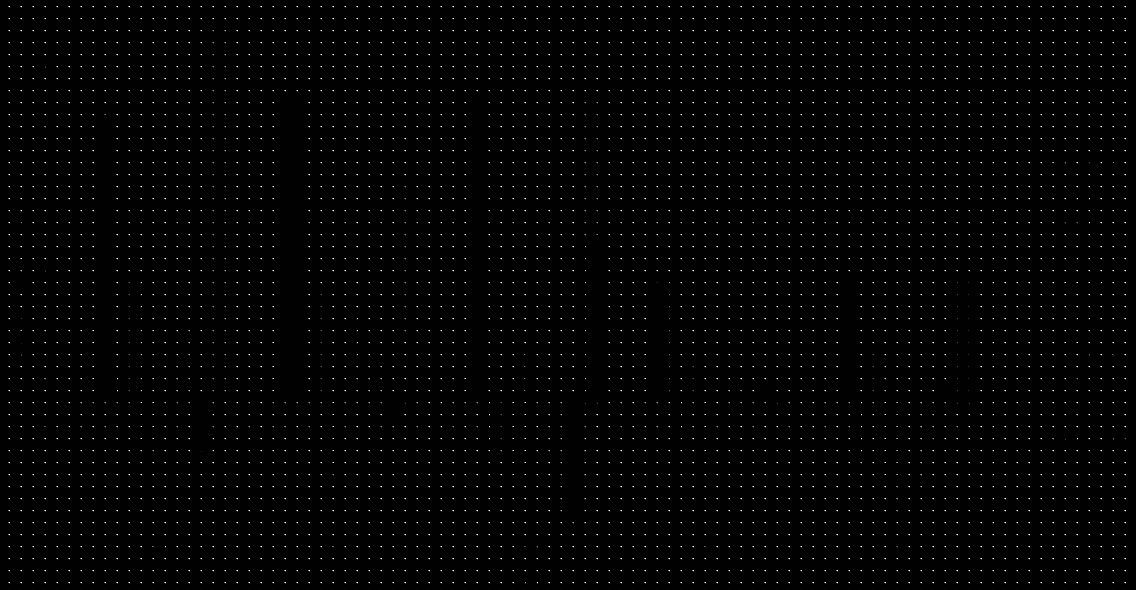

Source: IMF (2013b).

The data for the fiscal deficits in UNASUR countries, Figures 5 and 6, show that: (i) from 2000 to 2003, in general, the ratio nominal fiscal result/GDP had a bad performance; (ii) in 2004 and 2005, the nominal fiscal result became a little bit better for some countries, especially Chile; (iii) from 2006 to 2008, it improved for almost all countries (the exception was Uruguay); and (iv) in 2009 and 2010, there 
was great deterioration in the ratio nominal fiscal result/GDP. This deterioration, of course, can be explained by the countercyclical fiscal policies implemented by the monetary authorities in response to the 'great recession'. For instance, Brazil and Chile reduced the taxes to stimulate consumption and Argentina, Brazil and Colombia increased their public expenditure. Thus, the combination of short recession and some expansionary fiscal policy produced a reduction in the fiscal balance, in 2009, that quickly improved further in 2010 (Jará, Moreno \& Tovar, 2009).

Figure 5: Nominal Fiscal Result/GDP, 2000-2005

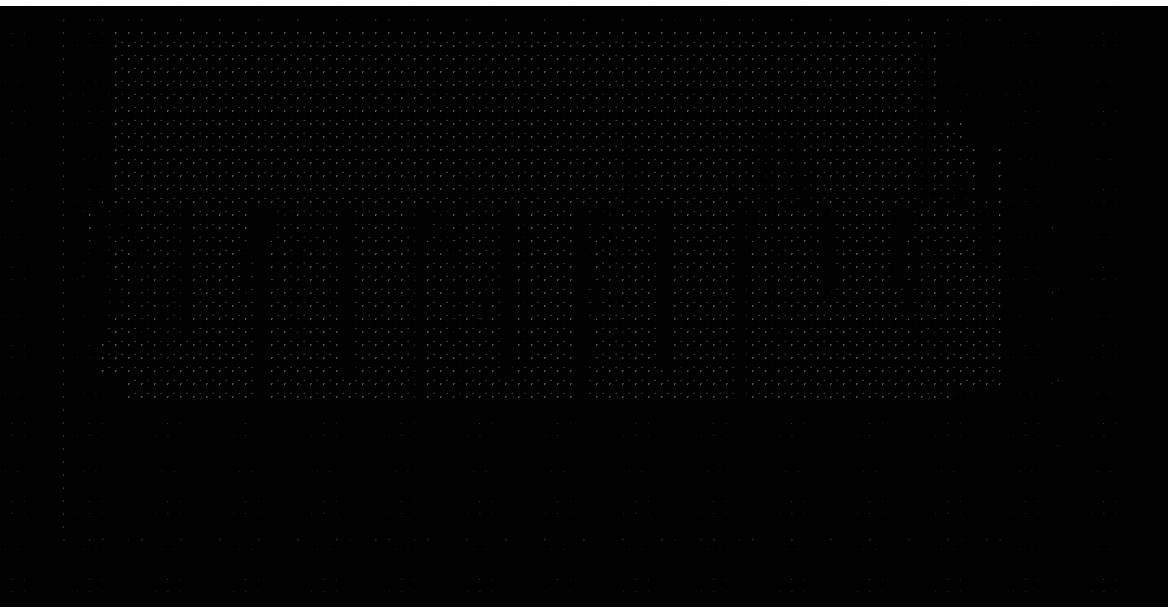

Source: ECLAC (2013).

Figure 6: Nominal Fiscal Result/GDP, 2006-2010

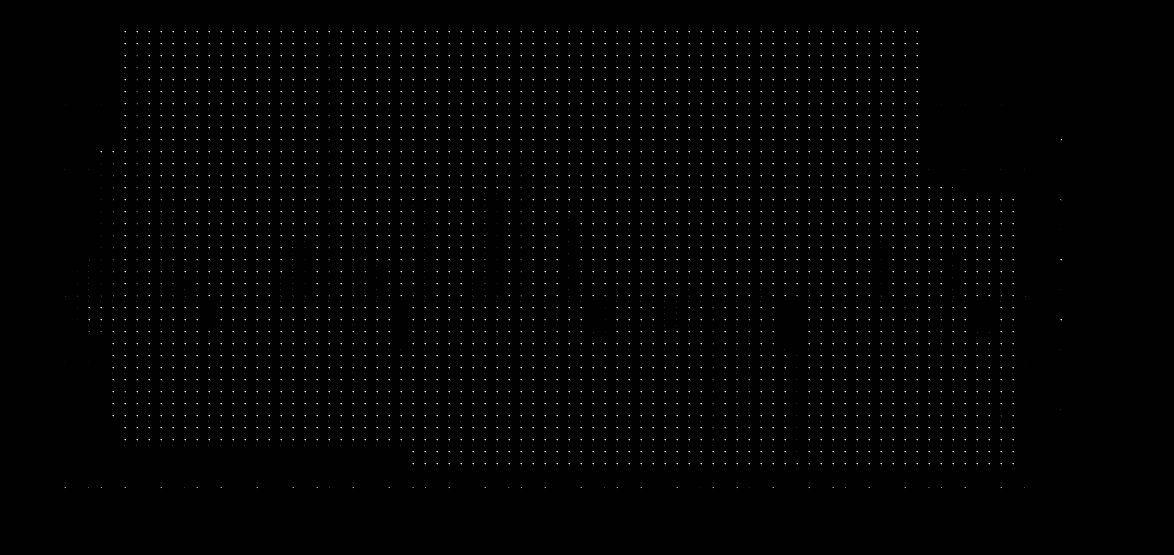

Source: ECLAC (2013). 
In terms of the ratio of gross public sector debt to GDP, Figures 7 and 8 show that: (a) after reaching $170 \%$ of GDP, the Argentinean gross public debt dropped, year after year, to $48 \%$ by 2010 ; (b) the Bolivian gross public debt was relatively stable, around $60 \%$, from 2000 to 2005, and after 2006 it dropped considerably; (c) the Brazilian gross public debt remained, during the period, around $65 \%$; (d) Chile presented the lowest ratio of gross public debt to GDP. Its gross public debt ranged between $15 \%$ and $20 \%$; (e) the Colombian gross public debt ranged between $30 \%$ and $40 \%$; (f) Ecuador, at the beginning of the 2000s, had a high gross public debt. However, after 2006 the gross public debt dropped rapidly, reaching $20 \%$ in 2010; (g) the gross public debt of Paraguay increased from 2000 to 2002 and, since 2003, has declined, year after year; (h) the Peruvian gross public debt ranged between $20 \%$ and $30 \%$; (i) from 2000 to 2003, the Uruguayan gross public debt increased rapidly and after 2004 it declined and remained stable around $60 \%$; and (j) the Venezuelan gross public debt, during the period, ranged between $30 \%$ and $40 \%$.

Figure 7: Gross Public Debt/GDP, 2000-2005

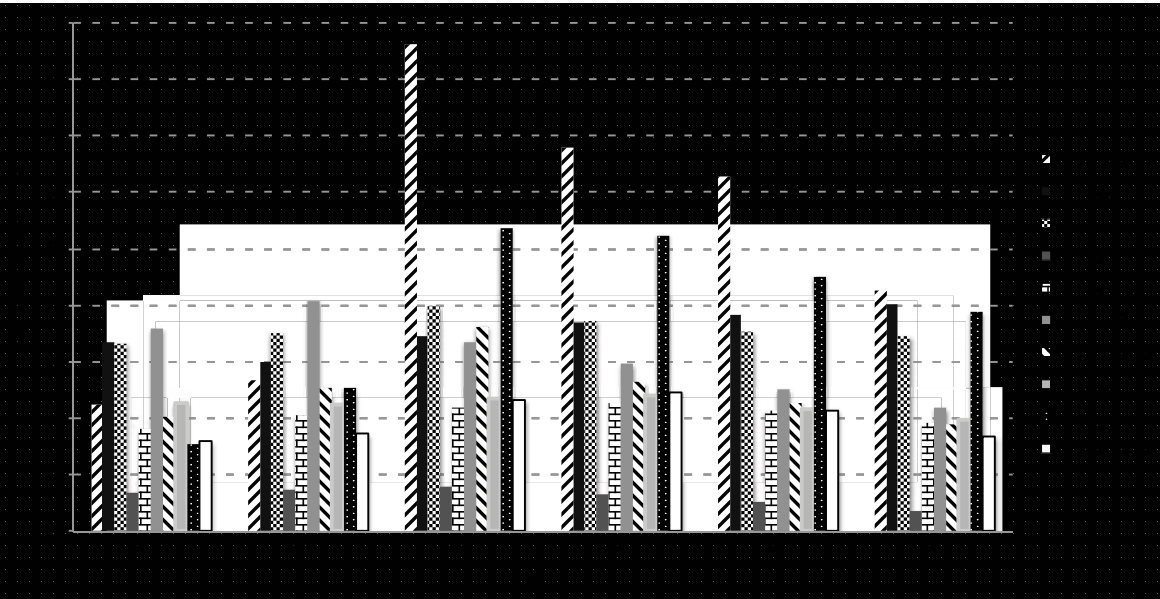

Source: IMF (2013b). 


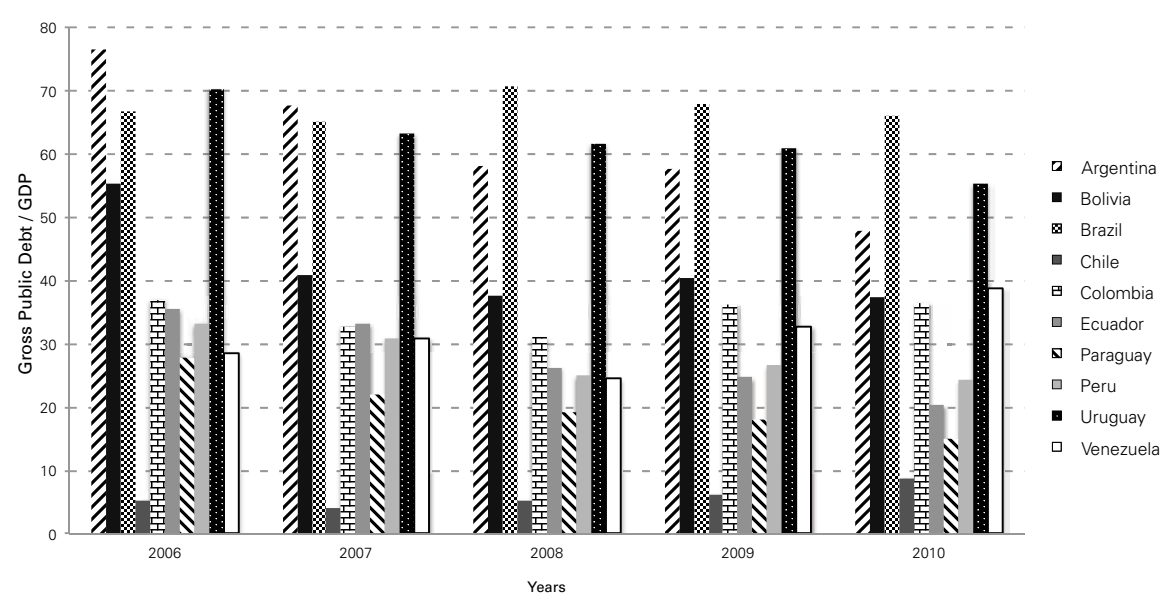

Source: IMF (2013b).

Finally, according to the data from IMF (2013b), Brazilian Central Bank (2013) and Central Bank of Ecuador (2013), the foreign reserves of the UNASUR countries, from 2000 to 2010, increased substantially: the total amount of foreign reserves in 2000 were around USD 106.9 billion, while in 2010 they reached USD 451 billion. With the exception of Venezuela, in which the total amount of foreign reserves became stable from 2000 to 2010 , the total amount of foreign reserves of the other nine countries of UNASUR increased significantly. The amount of foreign reserves of Bolivia and Brazil, for instance, increased seven times in the period.

Summarizing the macroeconomic and structural variables for UNASUR countries as discussed in this sub-section, we observed that: (a) average growth rate and inflation rate have been relatively similar for all countries. The exception was Venezuela, basically in terms of the inflation rate; (b) the unemployment rate decreased and converged, over the period, for all countries; (c) in general, the exchange rate regimes have been operated as a dirty floating system - with the exceptions of Ecuador and Venezuela - and has dominated the monetary regime of inflation targeting; (d) the volume of intraregional trade among the UNASUR countries is still low, but it improved from 2000 to 2010; (e) the relationship between current account and GDP, for all countries, was volatile over the period, showing a slight improvement in the last years of the series, despite the 'great recession'; (f) after 2005, the nominal fiscal result/GDP ratio, for all countries, improved considerably, even with the problems arising from the 'great recession' that forced countries to adopt countercyclical fiscal policies, deteriorating, thereby, the primary fiscal surplus; (g) the gross public debt/GDP ratio showed different performance for the UNASUR countries. However, the trend in the gross public debt/GDP was falling and tending towards stability; and (h) the total amount of foreign reserves increased, from 2000 to 2010, around 320\%. 
To conclude this section, it is important to mention that at the end of the 2000s, a set of factors contributed to the 'convergence' of the macroeconomic performance and to face the contagious of the international financial crisis in the main South America countries: (i) lower interest rates; (ii) public accounts in general improved with low level of indebtedness; (iii) inflation stopped rising (Argentina and Venezuela were the exception); current account deficits were reduced; (iv) competitive exchange rates emerged; (v) high level of foreign exchange reserves; (vi) reduced short-term external liabilities; and (vii) capital account regulations in place (Cunha, Prates \& Ferrari-Filho, 2011; Ocampo, 2012).

\section{A REGIONAL ARRANGEMENT PROPOSAL FOR UNASUR}

The previous section showed that, historically and analytically, the economic integration process in South America has become a reality. However, as we know, there are still some problems to be overcome, such as asymmetric cyclical conditions in the economies of the Region, which means that a growing disparity of the most-developed countries in comparison to the less-developed ones is observed. The latter seems to suffer from perverse consequences in the sense that capital and labor mobility is very low, the financial integration has not been completed and the intraregional trade still is very incipient.

In this context, starting from the assumption that the process of economic integration in South America can be consolidated by UNASUR, this section presents a regional arrangement proposal for UNASUR based on the creation of a Regional Market Maker that is capable of boosting trade and financial relations, discipline and standardize macroeconomic policies and to prevent any disruptive situation resulting from financial and exchange rate crises. Our inspiration is Keynes's revolutionary analysis presented in his International Clearing Union, during the Bretton Woods Conference in 1944.

As we know, the Keynesian economic analysis concerning the financial and currency crises in a global world shows that the real disruptive outcomes derived from speculation in liberalized financial markets can only be reduced (or eliminated) if there is a market maker institution able to (i) prevent the capital volatility, (ii) assure market price stability and (iii) promote full employment economic growth.

Taking into consideration this idea, we propose a regional arrangement for UNASUR to assure macroeconomic stability, understood as sustainable economic growth, inflation under control, fiscal adjustment and external equilibrium. To address this objective, it is necessary to create a UNASUR SUPRAREGIONAL BOARD (USB) with political powers to establish (i) the adoption of common rules for macroeconomic policies ${ }^{16}$, (ii) joint programs for removal of trade barriers, (iii) the use of national currencies for intraregional transaction, (iv) a stable exchange

\footnotetext{
${ }^{16}$ It is important to mention that we are not proposing targets and the same macroeconomic policies
} 
rate system, (v) conditions for eliminating the external imbalances, (vi) the management of foreign reserves, (vii) mechanisms of capital controls, (viii) fiscal transfer to reduce structural and economic disparities among the countries, and (ix) conditions to monitor and to prevent the market failures (Ferrari-Filho, 2001-2002).

The main idea of Keynes's International Clearing Union was

"the substitution of an expansionist, in place of a contractionist, pressure on world trade" (Keynes, 1944/1980, p. 176). Thus, Keynes suggested a scheme set out in a new international monetary system, based on an international currency, bancor, able to resolve the current financial crises and at the same time to promote full employment and economic growth in the global economy. Keynes clearly demonstrated what the world economy needed was "a central institution [...] to aid and support other international institutions”. (Ibid., pp. 168-169, emphasis added)

Going in the same direction, Gnos, Monvoisin and Ponsot (2011) propose the creation of an Unidad Central de Compensación, that is, a payment agreement system to facilitate payments among countries, to reduce 'transaction costs' by having their central banks act as clearing houses for payments among them etc. According to the authors, the member central banks would have to act as clearing houses for trade related payments of each member country vis-à-vis the others, settling the balances only every four months.

Contrary to Keynes (1944/1980) and Gnos, Monvoisin and Ponsot's (2011) proposals, we think that the USB does not require the establishment of a single currency to UNASUR. What is required, besides the institutional bodies created in the last three decades to boost the economic integration in the Region, is to design some rules for the governments and central banks of the UNASUR countries able to substitute the process of expanding effective demand in the South America, as occurred in the 1990s and 2000s, especially, in Argentina, Brazil and Uruguay.

In order to realize this objective, the USB should concentrate on pursuing creative policy options to reduce the real disruptive outcomes that emanate from speculative activity in financial and exchange rate markets. Thus, the USB should attempt the following policy objectives:

(i) To coordinate the macroeconomic policies among countries. It means that monetary policy should be employed to control the rate of interest, instead of controlling the stock of money to keep inflation under control, and fiscal policy should be discretionary to support aggregate demand and, by a transfer mechanism, to reduce economic and social differences and integrate among countries' infrastructures $^{17}$;

for countries that have distinct characteristics. In other words, this is not the idea that 'one size fits all', as it is implicit in the EMU institutional arrangement.

${ }^{17}$ The proposal is similar to that of the FOCEM. 
(ii) To assure that the central banks acts as a lender-of-last-resort to avoid bankruptcy of banks and financial collapse, as well as government default; as a result, disruption in the credit system related to productive activity would be avoided;

(iii) To implement a common trade policy and distribute the costs of achieving balance of payments equilibrium among the two groups of countries, those in deficit and those in surplus. The idea is similar, but on a large scale, to those existing in FLAR, as it section 2.1 shows;

(iv) To consolidate the free trade area in the UNASUR, which means to eliminate tariffs, import quotas and preferences on goods and services traded among the UNASUR countries. Currently, most trade relations among countries of the Region, for instance inside the MERCOSUR and the CAN, are determined by the principles of the Common External Tariff — that is, a standard trade duty adopted by a group of countries;

(v) To manage an exchange rate regime based on a fixed, but adjustable exchange rate system. As it is well known massive capital inflows as a consequence of large capital inflows in the form of both foreign direct investment and portfolio investment, fuelled by interest rate spreads between markets in the region and in developed economies, have produced macroeconomic problems in the main emerging countries of the region, including exchange rate appreciation and quick increase in domestic credit. Thus, the objective is to reduce the volatility of capital flows and to mitigate instability and fragility related to the speculative attacks on domestic currencies. In this context, on the one hand, reserve accumulation policies can be seen as insurance against negative shocks and speculation against domestic currency. On the other hand, another possibility is the use of capital management techniques, which includes capital controls, prudential domestic financial etc. (see, for more details, Ferrari-Filho \& Paula, 2008-200918);

(vi) To promote a system of local currency payments to boost the trade and financial relations among countries. The idea is to generalize the SML system.

It should be emphasized at this point that a lesson from the current 'euro crisis' is evident. Namely that in any integration, and the South American integration as discussed in this contribution is no exception, it is very important to have common countercyclical policies of the type of the United States of Europe for example, rather than of the EMU. A single policy based on a single objective of economic policy as in the EMU, with no other policy, is based on the wrong macroeconomic model. Further policies, and fiscal policy in particular, are paramount. This is par-

\footnotetext{
${ }^{18}$ Considering that five countries of South America have adopted the inflation targeting framework, a question that is raised is the following: how could inflation targeting and exchange rate targeting be compatible? Frenkel and Rapetti (2011) suggest a mix of administered exchange rate flexibility with active foreign exchange reserve accumulation, regulation of capital inflows and active sterilization of international reserves, combined with low domestic interest rates and fiscal restraint. To evaluate deeply the macroeconomic problems, and their consequences, to identify the trade-offs in economic policy, and to choose the right economic strategy, is the main challenge to economic policies in the South American countries.
} 
ticularly important in view of the existence of more than a single objective of economic policy as the 'great recession' has taught us recently. Co-ordination of policies across the regional integration is also important (see, for more details, ARESTIS, 2012).

In other words, our proposal removes all constrains on national-level fiscal and monetary policies, stabilizes the exchange rate, stimulates the trade relations, imposes limits on capital mobility, and encourages, through SML, intra-regional trade and cooperation and preserves foreign reserves. In sum, it reduces the entrepreneurial uncertainties and develops an institutional arrangement to assure full employment economic growth and to mitigate the regional inequality among the UNASUR countries.

\section{CONCLUSION}

We have argued that in the 2000s the debate on the need to consolidate a process of economic integration more consistently and robustly in South America came to be on the agenda. At least two reasons were fundamental to bring back the debate on economic integration in South America: on the one hand, a set of institutional bodies (FOCEM, Bank of the South and SML, among others) were created to boost the economic integration in the Region ${ }^{19}$; and, on the other hand, regional integration became the better alternative to the emerging economies to assure macroeconomic stability and avoid financial and exchange rate crises.

Going into this direction, the article analyzed, historically and analytically, the process of economic integration in South America, converging on the UNASUR. Our analysis showed that there is some evidence of macroeconomic convergence in UNASUR. For instance, (i) the average growth rate and inflation rate have been relatively similar for all countries, (ii) the unemployment rate decreased and converged, over the period, for all countries, (c) the effective real exchange rate became relatively stable for all countries, and, most importantly, (iv) the volume of intraregional trade among the UNASUR countries improved from 2000 to 2010: it increased $176.1 \%$.

In this context, considering that the convergence of some macroeconomic variables of the UNASUR countries indicate that, in the near future, it is possible to reach the stage of a common market in the Region, it was presented a proposal, based on Keynes' revolutionary analysis, for regional integration in UNASUR. Thus, the article proposed the creation of a Regional Market Maker to boost trade and financial relations, discipline and standardize macroeconomic policies and prevent any disruptive situation resulting from financial and exchange rate crises. In summary, what is expected from our proposal is (i) a deeply integrated market in the

\footnotetext{
${ }^{19}$ Deos, Mendonça and Wegner (2010) emphasizes the importance of monetary and financial cooperation to the Region.
} 
UNASUR and (ii) that South America's monetary authorities can operate, jointly and convergently, fiscal, monetary and exchange rate policies in such a way as to assure macroeconomic stability, understood as sustainable economic growth, inflation under control, fiscal adjustment and external equilibrium, in the Region.

To conclude, it is important to mention that the regional integration of South America, through UNASUR, is feasible, but it is politically difficult due to the fact that Chile, Colombia, Mexico and Peru are organizing a free trade and economic integration bloc, called Pacific Alliance, and Paraguay has strong restrictions to any integration process with Venezuela. However, it is another matter.

\section{REFERENCES}

ARESTIS, P. (2012). "Fiscal policy: a strong macroeconomic role". Review of Keynesian Economics, 0(1), 93-108, October.

ARESTIS, P.; FERRARI-FILHO, F. (2012). “Regional integration in South America”. Revista Venezolana de Análisis de Coyuntura. Vol.XVIII, n², pp.65-92, julio-diciembre.

ARESTIS, P.; FERRARI-FILHO, F.; PAULA, L.F.; SAWYER. M. (2003). "The euro and the EMU: lessons for Mercusor”. In: ARESTIS, P.; PAULA, L.F. (eds.). Monetary Union in South America: Lessons from EMU. Cheltenham: Edward Elgar, pp.14-36.

BAUMANN, R. (2001). “Mercosul: origens, ganhos, desencontros e perspectivas”. In: BAUMANN, R. (org.). Mercosul: avanços e desafios da integração. Brasília: IPEA, pp.19-68.

BRAZILIAN CENTRAL BANK (2013). Séries Temporais. http://www.bcb.gov.br. Access in September.

CENTRAL BANK OF ECUADOR (2013). Estadística. http://www.bce.fin.ec. Access in September.

COMUNIDA ANDINA DE NACIONES (CAN) (2013). Quiénes Somos. Available at: http://www.comunidadandina.org. Access in July.

CUNHA, A.M.; PRATES, D.; FERRARI-FILHO, F. (2011). "Brazil responses to the international financial crisis: a successful example of Keynesian policies?”. Panoeconomicus, 5 (special issue), pp.693-714.sue):69

DEOS, S.S.; MENDONÇA, A.R.R..; WEGNER, R.C. (2010). “Cooperação financeira regional no Mercosul e o financiamento do investimento". Anais do III Encontro da Associação Keynesiana Brasileira. São Paulo, cd-rom, August.

ECONOMIC COMMISSION FOR LATIN AMERICA (2013). Información Estadística. http://www. eclac.cl. Access in September.

FERRARI-FILHO, F. (2001-2002). "Why does it not make sense to create a monetary union in MERCOSUR? A Keynesian alternative proposal”. Journal of Post Keynesian Economics, 24(2), Winter, pp.235-252.

FERRARI-FILHO, F.; PAULA, L.F. (2008-2009). "Exchange rate regime proposal for emerging countries: a Keynesian perspective”. Journal of Post-Keynesian Economics, 31(2), pp.227-248.

FRENKELL, R.; RAPETTI, M. (2011). "Fragilidad externa o desindustrialización: cuál es la principal amenaza para América Latina en la próxima década?”. Serie Macroeconomia del Desarrolo $n^{\circ}$ 116, Santiago del Chile: CEPAL, November.

GNOS, C.; MONVOISIN, V.; PONSOT, J-F. (2011). "Proposal for a regional clearing union in South America". Proceedings of the IV International Congress of the Brazilian Keynesian Association, Rio de Janeiro, August.

INTER-AMERICAN DEVELOPMENT BANK (2005). Mercosur Report. http://www.iadb.org. Access on August 2013.

INTERNATIONAL MONETARY FUND (2013a). World Economic Outlook Database. http://www. imf.org. Access in September.

(2013b). Data and Statistics. http://www.imf.org. Access in September. 
JARÁ, A.; MORENO, R.; TOVAR, C.E. (2009). "The global crisis and Latin America: financial impact and policy responses". BIS Quarterly Review, June, pp.53-68.

KEYNES, J.M. (1944/1980). Activities 1940-1944: Shaping the Post-War World, the Clearing Union. London: Macmillan (The Collected Writings of John Maynard Keynes, Vol. 25, edited by Moggridge, D.).

MINSKY, H. (1986): Stabilizing an Unstable Economy. New Heaven: Twentieth Century Fund Report.

OCAMPO, J.A. (2012). "Balance of payments dominance: its implications for macroeconomic policy". https://www.mtholyoke.edu/.../Ocampo_Macro_Mount_Holyoke.pdf. Access on August 2013.

UNIÓN DE NACIONES SURAMERICANAS (UNASUR) (2013). Información Básica. http://www. uniondenacionessuramericanas.com. Access in July.

UNITED NATIONS CONFERENCE ON TRADE AND DEVELOPMENT (2007). Trade and Development Report. http://www.unctad.org. Access on July 2013. (2008). Evolution of Commodity Price. http://www.unctad.org. Access on August 2013. . (2013). Statistics. http://www.unctad.org. Access in September.

UNITED NATIONS DEVELOPMENT PROGRAMME (2013). Human Development Reports. http:// www.hdr.undp.org. Access in August. 